\title{
Innovative Financial Instruments in EU Funding Schemes
}

\author{
Eva Branten \\ Alari Purju \\ Department of Public Economics, \\ Tallinn University of Technology \\ Akadeemia tee 3, \\ Tallinn 12618, Estonia \\ E-mail: evabranten@gmail.com \\ E-mail: alari.purju@ttu.ee
}

\begin{abstract}
Innovative financial instruments, in the context of the funding schemes of the European Union, are different from funding by way of direct subsidies. These financial instruments can be divided in two large groups: instruments offering risk capital and equity capital and debt instruments. The instruments help to engage resources from the private sector in projects which might be considered too risky without the said instruments and the implementation of which would be impossible or related to significantly higher expenses for the promoter of the project. As seen from Estonia's perspective, up until now the use and impact of innovative financial instruments have generally met the expectations. In view of the diversity of areas and target groups of the innovative financial instruments planned within the framework of European Union's Financial Framework 2014-2020, it may be presumed that several new instruments will be successfully implemented in Estonia.
\end{abstract}

Keywords: debt instruments, European Union's funding schemes, innovative financial instruments, multiplier effect, social cost-benefit analysis 


\section{Introduction}

In the context of the funding schemes of the EU, innovative financial instruments are the financial instruments which are different from funding by way of direct subsidies. The concept embeds a great number of funding schemes, among them, for instance, funding with a combination of subsidy grant and loan. These financial instruments can be divided in two large groups: instruments offering risk capital and equity capital, and debt instruments (e.g., loans and guarantees to financial intermediaries, who, in turn, offer loans to the instrument's target group). Innovative financial instruments help to engage resources in private sector's projects, which without assistance from such instruments might be considered too risky for the private sector, and the implementation of these would therefore be impossible or related to significantly higher expenses for the promoter of the project. In the EU budget, according to the plan, the share of innovative financial instruments in the EU budget will be significantly increased in the course of the Financial Framework 2014-2020. Therefore it is imperative that innovative financial instruments and their impact are taken into consideration on a wider scale.

The article consists of three parts. In the first part, the authors analyse the essence of innovative financial instruments and the general aims that these instruments pursue. The second part describes the instruments planned within the EU's new Financial Framework. The authors compare the financial instruments in use and those planned within the framework of the next Financial Framework. In the third part, the authors suggest a model of analysis for the estimation of the social costs and benefits of innovative financial instruments, based on the principles of social cost-benefit analysis. The article presents the potential social benefits and costs of innovative financial instruments and ways to measure their impact and concludes with some recommendations regarding the use of innovative financial instruments in Estonia.

\section{Innovative financial instruments}

Innovative funding schemes have been directed at widely different investment cases, which show great promise and are very likely to turn out viable and feasible, which at the same time cannot attract adequate resources from the market, at least for the time being. Under the EU's "Europe 2020" strategy, these instruments fulfil the following goals (European Commission, 2011a): 
- Supporting private sector to generate economic growth and innovation, create jobs, and alleviate social alienation;

- Contributing to competitiveness and sustainability of the European Union in areas of transportation, energy and environment, by supporting the building of infrastructure objects;

- Supporting engagement of private sector at providing public benefits through various mechanisms.

By reference to the aforementioned, a major goal set for innovative financial instruments is bolstering innovation and development activities. Public sector support to innovation and R\&D activities is seen as wholly justified, because too often there is no market demand for information obtained in the process of R\&D activities (Bozeman \& Rogers, 2001).

Concomitant to the use of innovative financial instruments is multiplier effect, because the said instruments favour and stimulate funding of certain projects also by such public or private sector investors who would not otherwise have invested into the project, or would have invested less. For that matter, innovative financial instruments can be viewed as an example of private and public sector cooperation, whereby innovative financial instruments can be seen as conforming to the concept of 'new public management'. In general terms, the diversification and sharing of risks between the private and the public sector, the growing scale effect, making use of the private sector's knowledge and skills at projects viable from the society's viewpoint may be regarded, among other things, as the advantages of private and public sector cooperation (Turhani \& Shqau, 2011).

Private and public sector cooperation also helps to avoid crowding out of private investments (European Commission, 2011a). The importance of private (particularly banking and financial sector) and public sector partnership in diminishing the risks of implementation of innovative financial instruments is also emphasised by the report considering cooperation on the funding of financial instruments of the European Parliament, the European Investment Bank and the European Reconstruction and Development Bank (Bain \& Robinson, 2011).

An important aspect of public and private sector cooperation is also that for the public sector it should be possible to diversify expenditures related to large infrastructure projects during the viable life of the infrastructure objects. The impact of diversification of expenditures allows the implementation of large infrastructure projects also in the period of constrained fiscal policy, because the impact on government sector budget is smaller. Private and public sector partnership in the EU energy and telecommunications areas is considered particularly promising 
(Commission of the European Communities, 2009). Heretofore the important areas of private and public sector partnership in the European Union have been production, building and transport (European Commission, 2011d).

Innovative financial instruments will not oust traditional subsidies from the EU structural funds; however, the share of innovative financial instruments in the EU budget will grow significantly in the period of Financial Framework 2014 2020. In the present period of the EU Financial Framework 2007-2013, the EU expenditures on innovative financial instruments constitute below one per cent of the EU budget. Innovative financial instruments are only targeted at certain classes of assets and at the diversification of certain risks. It is to the point here to note that according to the assessment of the European Commission, innovative financial instruments will not constitute a larger risk to the EU budget than the traditional structural funds' subsidies, while the use of innovative financial instruments may bring new receipts to the budget (e.g., interest income) (European Commission, 2011a).

By return on the capital received from financial instruments during their life and the renewed use of interest as financial instruments emerges the multiplier effect, which allows to consider these financial instruments as cost-effective (European Commission, 2011a). The direct impact of the activities, implemented in Estonia within the framework of the additional support programme of the EU's Financial Framework 2007-2013 to enhance the availability of the entrepreneurs' loan capital, has been estimated to amount to 190 million euros, while the direct pecuniary contribution was 80 million euros (Approval of programme, 2009).

According to the estimate of the European Commission, the use of innovative financial instruments brings about not only financial impacts but also benefits which cannot be directly measured in monetary terms, such as the development of risk capital markets and their becoming more refined. Also, institutions on the national and local level may "borrow" the knowledge of EU institutions when forming their financial schemes. Nor are there guarantee schemes in several EU Member States, among which the EU guarantee scheme offered under Competitiveness and Innovation Framework Programme may serve as a good example (European Commission, 2011a). The implementation of innovative financial instruments by the EU must be, according to the European Commission, in compliance with the subsidiarity principle and the principle that EU's intervention must not cause market faults and inefficiency (European Commission, 2011a). 


\section{EU financial framework $2014-2020$ instruments}

The figure below shows the innovative financial instrument system to be developed on the EU level within the European Union financial framework 2014-2020.

Figure 1. A system of innovative financial instruments to be prepared and carried out on the EU level within the European Union Financial Framework 2014-2020

\begin{tabular}{|c|c|}
\hline \multicolumn{2}{|c|}{ Innovative financial instruments } \\
\hline Risk and equity capital instruments & Debt instruments \\
\hline $\begin{array}{l}\text { Equity capital instrument for } \\
\text { innovation and development }\end{array}$ & $\begin{array}{l}\text { Debt instruments to support } \\
\text { innovation and development activity }\end{array}$ \\
\hline $\begin{array}{l}\text { Risk capital instrument for seed phase } \\
\text { investments to SMEs }\end{array}$ & $\begin{array}{l}\text { Project bonds to support building } \\
\text { infrastructure objects }\end{array}$ \\
\hline & Debt instrument to SMEs \\
\hline $\begin{array}{l}\text { Equity capital instrument to support } \\
\text { infrastructure objects }\end{array}$ & $\begin{array}{l}\text { Guarantee instruments in educational } \\
\text { and cultural area }\end{array}$ \\
\hline
\end{tabular}

Source: Composed by authors after EC documents

To support innovation and development activity during the Financial Framework 2014-2020 period, the European Commission plans to put into action the following innovative financial instruments on the EU level (European Commission, 2011a):

- Debt instrument - to provide loans for research and development activity investments and give guarantees to financial intermediaries who will distribute loans to companies and institutions in compliance with goals of the instrument, or enable combinations of loan and guarantee;

- Equity capital instrument - for investments to risk capital funds, offering funding with the equity capital to R\&D intensive SMEs in the seed phase, and to support investments in development and innovation areas through funds of a wide international investor base.

To support competition and SMEs, the following instruments are planned to be taken into use on the European Union level (European Commission, 2011a): 
- Risk capital instrument - for seed phase investments, mainly to provide risk capital to SMEs through financial intermediaries. Differentiation is made between two instruments:

- Direct investments to risk capital funds, operating across borders within the European Union, which focus on growth-oriented companies and need not necessarily be related specifically to research and development activity;

- Investments funds, which in their turn invest in risk capital funds, which invest in companies in the phase of international expansion.

- Debt instrument to share the risks of financial intermediaries in order to provide loans to SMEs.

In order to promote self-employment, the establishment of micro-companies and social companies, the implementation of the already existing Progress Micro-finance Facility Instrument will be continued as planned (EU, 2010). The said instrument will be extended to support the establishment and institutional capacity of institutions which offer micro-credit - that is, supported are financial intermediaries which fund social investment funds and other financial intermediaries which fund social companies (European Commission, 2011a)

To support infrastructure objects within the framework of Connecting Europe Facility, the implementation of the following innovative financial instruments is planned on the EU level (European Commission, 2011a):

- Risk sharing instrument, embracing loans and bonds (incl. project bonds within the framework of European Union's strategy "Europe 2020");

- Equity capital instrument.

Underlying the detailed elaboration of "Europe 2020" project bonds is the project bonds pilot phase in 2012-2013. The project bonds are targeted at infrastructure projects in the areas of transportation, energy and information and communications technology. The motive behind creating project bonds was the difficult access of the said areas to long-term loan capital. Long-term bonds are considered very suitable for funding particularly infrastructure projects due to the relatively stable and predictable cash flows of the latter (European Commission, 2011b). In respect of the methods and procedures necessary for operating the project bonds, the TEN-T loan guarantee instrument methods and procedures, presently in use as a funding scheme, are largely relied on. Unlike the TEN-T loan guarantee instrument, the target group of project bonds also includes the energy and telecommunications sectors (European Commission, 2011c; 2011e). 
In the area of education and culture, the developing of guarantee instruments which would be based on the goals of the European Union strategy "Europe 2020 " is planned on the EU level. The guarantee instruments are the following (European Commission, 2011a):

- Instrument to guarantee the study loan, enabling master students to study abroad, to fulfil the European Union goal that 20 per cent of students having acquired higher education should have participated in students' cross-border mobility programmes;

- Guarantee instrument to facilitate obtaining loans through financial intermediaries for SMEs operating in culture-and creativity-related areas.

In what follows, a comparison of cash flows related to innovative financial instruments and traditional subsidies is presented on the example of an eventual case of implementation of start-up loans (innovative financial instrument) and start-up grants (subsidy).

\section{Example}

Suppose company A is a firm starting operations, but has a shortfall of 7,000 euros in funds to purchase capital assets. To fund the purchase of capital assets, the company can apply through Enterprise Estonia within the framework of the European Union Social Fund for the start-up grant (traditional subsidy) or within the framework of the start and micro-loan insurance programme, funded by the European Union Social Fund via Foundation KredEx, for the start-up loan (innovative financial instrument).

In terms of the start-up grant, the maximum amount of support is 7,000 euros. The company also has to self-finance the project, for the funding of which the grant is requested (in the given example, the acquisition of capital assets), in the amount of at least 20 per cent. Therefore, the sum of self-financing to apply for the grant in the amount of 7,000 euros must be at least 1,750 euros. When considering and assessing the opportunity to apply for the start-up grant the company should take into account the amount required for self-financing. If the company lacks the required 1,750 euros and needs an additional bank loan for that purpose, all costs related to the bank loan must be considered; if the company happens to own the sufficient amount for self-financing, it should consider the opportunity cost of a prompt use of that amount. 
From the financer's position, the start-up grant is a one-off payout, which is not followed by company's remuneration to the financer, or by any future-related obligations for the financer.

The start-up support programme offers surety loans from the means of the European Union Social Fund. The extent of the surety is 75 per cent of the outstanding loan amount. For the start-up loan, the rate of self-financing required from the applicant company is lower than with the start-up supportwith investment loans the required self-financing is at least 10 per cent of the project's cost. Thus, self-financing for applying for a loan of 7,000 euros must be at least 778 euros. The loan term within the start-up loan programme can be up to 60 months. Taking into account that the maximum size of start loan is 64,000 euros, whereas in this example the loan amount was 7,000 euros, the assumed term of the loan could be 12 months. Under the assumption, the per annum interest rate of the start-up loan could be 8 per cent. This means that the company must reckon an interest expense of 560 euros when applying for a 7,000 euro start-up loan. In addition, the up-front fee for closing the surety agreement is 0.5 per cent of the loan amount. With the 7,000 EUR loan, the surety agreement fee is 35 euros. The start-up loan (in this case 7,000 euros) must be repaid in full. When applying for the start-up loan, the owners of the company, that is private individuals, also have to reckon the requirement of the surety's solidary liability for company owners as private individuals (30-40\% of the loan amount). This means that the owners of the company could accrue a liability to pay 2,100 to 2,800 euros in the future.

The provider of the surety instrument does not incur a prompt monetary payment when the instrument is implemented; however, they will accrue the liability which might realise in the future. The size of the eventual liability (i.e. surety) is 75 per cent of the amount of the outstanding loan. With the 7,000 euro start-up loan, the maximum size of eventual liability will be 5,250 euros.

Comparison of the start-up grant and start-up loan from the perspective of the company and the financer of programme has been presented in Tables 1 and 2 . 
Table 1. Comparison of the start-up support and the start-up loan from the company's position

\begin{tabular}{|l|l|}
\hline $\begin{array}{l}\text { Subsidy (start-up grant) from the } \\
\text { company's position (beneficiary of } \\
\text { subsidy) }\end{array}$ & $\begin{array}{l}\text { Innovative financial instrument } \\
\text { (start-up loan) from the company's } \\
\text { position }\end{array}$ \\
\hline $\begin{array}{l}\text { Self-financing: at least 1,750 euros } \\
\text { for a 7,000 euro subsidy }\end{array}$ & $\begin{array}{l}\text { Self-financing: at least 778 euros for a } \\
7,000 \text { euro start-up loan }\end{array}$ \\
\hline $\begin{array}{l}\text { Expenses related to fulfilment of self- } \\
\text { financing requirement - either direct } \\
\text { expense or alternative expense }\end{array}$ & $\begin{array}{l}\text { Interest expense: for a 7,000 euro start- } \\
\text { up loan, the per annum interest rate is } \\
8 \% \text { and the term 12 months 560 euros }\end{array}$ \\
\hline & $\begin{array}{l}\text { Fee for closing the surety agreement: } 35 \\
\text { euros for a 7,000 EUR start-up loan }\end{array}$ \\
\hline & $\begin{array}{l}\text { Repayments of loan totalling 7,000 } \\
\text { euros }\end{array}$ \\
\hline
\end{tabular}

Source: Composed by authors

Table 2. Comparison of the start-up grant and the start-up loan from the position of the programme's financer

\begin{tabular}{|l|l|}
\hline $\begin{array}{l}\text { Subsidy (start-up grant) from the } \\
\text { position of financer (grantor of } \\
\text { subsidy) }\end{array}$ & $\begin{array}{l}\text { Innovative financial instrument } \\
\text { (start-up loan) from the position } \\
\text { of the provider of instrument }\end{array}$ \\
\hline $\begin{array}{l}\text { One-off payment: } 7,000 \text { euros with } \\
7,000 \text { euro subsidy }\end{array}$ & $\begin{array}{l}\text { Liability which may be accrued in the } \\
\text { future: surety amounting outside 5,250 } \\
\text { euros for a 7,000 euro start-up loan }\end{array}$ \\
\hline
\end{tabular}

In general terms, when the projects financed through innovative financial instruments are successful and viable, it is possible that by monetarily supporting the projects, no real monetary outlay is incurred from the European Union's budget or the temporarily loaned amounts can be reinvested within the framework of innovative financial instruments or as subsidies of traditional structural funds. More specifically, in the case of innovative financial instruments we are often dealing with loans or guarantees.

Source: Composed by authors 


\section{Social cost-benefit analysis}

For funding the implementation of the project from public means (in the given case from the EU), the provider of the instrument must assess project-related risks. Although the project-related risks and the project's necessity, viability and compliance to requirements is always assessed when supports from the traditional EU structural funds are distributed, the projects' assessment process with innovative financial instruments is of particular importance, because in addition to channelling the public means, also the private sector's investments are affected by the said instruments. Thus, both the social expense arising from the failure of projects and the social benefits accompanying success of projects will increase.

Several expenditures of more direct type are related to the thorough appraisal of projects and elaboration of decision-making processes. Besides that, expenditures are incurred by presenting innovative financial instruments to target and associate groups of instruments. Compared to the appraisal of projects in the private sector, the appraisal of projects when using public means through innovative financial instruments calls for carrying out a social cost-benefit analysis, in which due consideration is given to project-related externalities, income and expense to different social groups, and time value of money.

According to its definition, social cost-benefit analysis is a method of economic appraisal of a project, programme or policy, which in monetary value measures all income and expenses which emerge with the implementation of the project or programme to the society. The analysis involves both the economic approach, in which the expense on using a resource is not regarded as monetary expense, incurred for the acquisition (use) of the resource, but as a revenue (benefit) that the given resource could have, put in the best alternative use (the price of the use of resource is the opportunity cost of resource), and from the society's position, an approach in which all project or programme related benefits and costs, accrued to the society, have been taken into account (Boardman et al., 2006).

Under the principles of the social cost-benefit analysis, the following benefits and expenses are considered when using innovative financial instruments: the impact of financial instruments on society through projects funded by them, the impact on capital markets, the impact on the EU budget and the broader use of public means. It is presumed that the innovative financial instruments are implemented in the best possible way. This means that eventual additional costs are not taken into account, which, for example, might accrue upon uncoordinated 
overlapping of goals, target groups of instruments, etc. (such problems have been implied by the European Commission and by independent experts in their reports; European Commission, 2011a). Social benefits and costs related to innovative financial instruments have been summarized in Table 3 .

General restrictions in the strategic management of public sector projects may be regarded more as indirect risk, including external pressure and political cycles, controversial goals on various levels of political hierarchy, red tape, and rigidity in adapting to changes in time (Bozeman \& Rogers, 2001).

When estimating the social benefits and costs accompanying the innovative financial instruments, it is possible to refer, to a certain extent, to the experience already existing in the European Union in implementing innovative financial instruments. In this regard, however, it is important to remember that the period of implementation of such instruments has been rather short, and the number of projects funded through them has been relatively small, and in general, with respect to future events there always remains certain insecurity.

To measure the benefits and costs related to innovative financial instruments in the most general sense, one should analyse individually each project funded through innovative financial instruments. It means that a large number of separate social cost-benefit analyses should be carried out, focusing only the projects which would not have been implemented without the involvement of innovative financial instruments. Also the projects which could have been implemented without the involvement of innovative financial instruments should be taken under scrutiny, as the instruments helped to substantially decrease the implementing costs. The difference of costs related to the implementation of the project would then be a direct benefit from the innovative financial instruments. 
Table 3. Social benefits and costs accompanying innovative financial instruments

\begin{tabular}{|c|c|}
\hline Social benefits & Social costs \\
\hline $\begin{array}{l}\text { Projects useful from the position of society are } \\
\text { implemented. }\end{array}$ & $\begin{array}{l}\text { Costs related to a thorough appraisal of } \\
\text { projects-elaboration of methods, criteria for } \\
\text { making decisions, etc. and carrying out an } \\
\text { appraisal of each project. }\end{array}$ \\
\hline $\begin{array}{l}\text { Projects useful from the society's perspective } \\
\text { may involve the resources of the private sector } \\
\text { under more favourable conditions-projects } \\
\text { useful to the society are implemented at lesser } \\
\text { costs. }\end{array}$ & $\begin{array}{l}\text { Costs related to the presentation of innovative } \\
\text { financial instruments. }\end{array}$ \\
\hline $\begin{array}{l}\text { Positive multiplier effect, which occurs when } \\
\text { the project the funding of which is supported } \\
\text { through innovative financial instrument, turns } \\
\text { out to be successful, because due to the use of } \\
\text { innovative financial instruments, private capital, } \\
\text { besides public means, has been invested into } \\
\text { the project. }\end{array}$ & $\begin{array}{l}\text { Increase in the public sector's risks and } \\
\text { responsibility, when funding the projects } \\
\text { through innovative financial instruments, } \\
\text { because with the help of innovative financial } \\
\text { instruments, the investment decisions of the } \\
\text { private sector are also affected. }\end{array}$ \\
\hline $\begin{array}{l}\text { Through innovative financial instruments the } \\
\text { goals can be achieved without losing the } \\
\text { possibility to reinvest the money allocated for } \\
\text { funding into other projects. }\end{array}$ & $\begin{array}{l}\text { Upon failure of the project funded through } \\
\text { innovative financial instruments-the loss of } \\
\text { public means; also the risk concomitant with } \\
\text { assuming liabilities related to future. }\end{array}$ \\
\hline $\begin{array}{l}\text { Attitude of private sector into innovative } \\
\text { projects may become more acceptable. }\end{array}$ & $\begin{array}{l}\text { The difference between possible lower (direct) } \\
\text { costs of alternative funding of projects and } \\
\text { direct costs related to the funding of projects } \\
\text { through innovative financial instruments. }\end{array}$ \\
\hline \multicolumn{2}{|l|}{$\begin{array}{l}\text { Developing and strengthening of capital } \\
\text { markets-innovative financial instruments } \\
\text { further competition between banks and bond } \\
\text { markets. }\end{array}$} \\
\hline \multicolumn{2}{|l|}{$\begin{array}{l}\text { Compared with traditional subsidies, the } \\
\text { innovative financial instruments take the needs } \\
\text { of the market more into account. }\end{array}$} \\
\hline \multicolumn{2}{|l|}{$\begin{array}{l}\text { Conditions of implementing innovative financial } \\
\text { instruments at a specific project can be } \\
\text { adapted, taking into account the specific nature } \\
\text { of the project. }\end{array}$} \\
\hline $\begin{array}{l}\text { With support from innovative financial } \\
\text { instruments it is possible to implement } \\
\text { specifically large scale European cross-border } \\
\text { projects. }\end{array}$ & \\
\hline
\end{tabular}

Source: Composed by authors 


\section{Summary}

In the context of the financing schemes of the EU, innovative financial instruments are such financial instruments which noticeably stand apart from funding by direct subsidies. Thus the concept "innovative financial instruments" incorporates a number of funding schemes such as, for instance, the funding by combination of a subsidy and a loan. Innovative financial instruments are divided in two main groups: instruments offering risk capital and equity capital, and loan instruments (e.g., loans and guarantees to financial intermediaries who, in their turn, offer loans to the instrument's target group). Innovative financial instruments help to include resources from the private sector by projects which the private sector might consider too risky as it lacks the help from the above instruments, and the implementation of which would be impossible or would incur significantly higher expenditures to the project's promoter. The share of innovative financial instruments is planned to be increased substantially during the EU Financial Framework 2014-2020. It is therefore imperative that the rationale of innovative financial instruments is understood and their impact appreciated in a wider context.

Eva Branten graduated from the School of Economics and Business Administration at the Tallinn University of Technology in 2012. She is a project research associate at Interreg project SmartComp at the Department of Public Economics of the Tallinn University of Technology.

Alari Purju, PhD (1988) is Professor and head of the Chair of Public Economics at the Tallinn University of Technology. His fields of interest are economic development problems, EU economics, and institutional economics. He has been advisor to the Minister of Economic Affairs and Communications in Estonia, has been working as a consultant to the OECD, the World Bank and to the Council of Higher Education of Latvia. He is a visiting professor at the Lappeenranta University of Technology. Alari Purju has managed or participated in four EU FP5 and FP6 projects, in OECD and the World Bank projects. His latest publication in BJES is "Euro Crisis, Old and New Trilemmas and Estonia's position" (BJES, vol. 2, no. 1[11]). 


\section{References}

Approval of programme (2009), Programmi “Ettevõtjate laenukapitali kättesaadavuse parandamise täiendav tugiprogramm" kinnitamine (2009) [Approval of programme "Additional support programme enhancing availability of the entrepreneurs' loan capital"; in Estonian]. Regulation of the Ministry of Economy and Communication in Estonia as of 2 April 2009, no. 101.

Bain, R. \& Robinson, N. (2011), The Implications of EIB and EBRD Co-financing for the EU Budget, Brussels: European Parliament's Committee on Budgets. Retrieved from http://www.polis.leeds.ac.uk/assets/files/Staff/eu-budget-report-11-robinson. pdf [accessed 2 May 2012]

Boardman, A. E.; Greenberg, D. H.; Vining, A. R. \& Weimer, D. L. (2006), CostBenefit Analysis: Concepts and Practice, $2^{\text {nd }}$ edition, New Jersey: Pearson Prentice Hall.

Bozeman, B. \& Rogers, J. (2001), 'Strategic management of government-sponsored R\&D portfolios,' Environment and Planning C: Government and Policy, vol. 19, pp. 413-442. http://dx.doi.org/10.1068/c1v

Commission of the European Communities (2009). Mobilising Private and Public Investment for Recovery and Long Term Structural Change: Developing Public Private Partnerships. Retrieved from http://eur.lex.europa.eu/LexUriServ/ LexUriServ.do?uri= COM:2009:0615:FIN:en:PDF [accessed 2 May 2012]

EU (2010), Opinion of the Committee of the Regions on "Progress Microfinance Facility," Official Journal of European Union, no. 79, pp. 71-79.

European Commission (2011a), A Framework for the Next Generation of Innovative Financial Instruments - the EU Equity and Debt Platforms. Retrieved from http:// ec.europa.eu/economy_finance/financial_operations/investment/europe_2020/ documents/com2011_662_en.pdf [accessed 7 Mar 2012]

(2011b), A Pilot for the Europe 2020 Project Bond Initiaitve. Retrieved from http:// ec.europa.eu/economy_finance/financial_operations/investment/europe_2020/ documents/com2011_660_en.pdf [accessed 30 Jan 2012]

(2011c), Excecutive Summary of the Impact Assessment (A Pilot for the Europe 2020 Project Bond Initiative). Retrieved from http://ec.europa.eu/ economy_finance/financial_operations/investment/europe_2020/documents/ sec2011_1239_en.pdf [accessed 10 March 2012]

(2011d), New Public-Private Partnerships for Research in the Manufacturing, Construction and Automotive Sectors, Luxembourg: Publications Office of the European Union.

(2011e), Proposal for a Regulation of the European Parliament and of the council amending Decision No 1639/2006/EC establishing a Competitiveness 
and Innovation Framework Programme (2007-2013) and Regulation (EC) No 680/2007 laying down general rules for the granting of Community financial aid in the field of the trans-European transport and energy networks. Retrieved from http://ec.europa.eu/economy_finance/financial_operations/investment/ europe_2020/documents/com2011_659_en.pdf [accessed 15 Feb 2012]

Turhani, A. \& Shqau, G. (2011), 'Public-Private Partnerships-For and Against,' China-USA Business Review, vol. 10, no. 9, pp. 893-898. 